E3S Web of Conferences 1, 04006 (2013)

DOI: $10.1051 / \mathrm{e} 3$ sconf/20130104006

(C) Owned by the authors, published by EDP Sciences, 2013

\title{
Pedogeochemical Anomalies in Surroundings of Great Cormorant Colony (Case Study in Lithuania)
}

\author{
$\underline{\text { R. Taraškevičius }}^{1}$, J. Motiejūnaitè ${ }^{2}$ and R. Zinkutè ${ }^{1}$ \\ ${ }^{1}$ Laboratory of Geoenvironmental Research, Nature Research Centre Institute of Geology and Geography, T. Ševčenkos \\ 13, LT-03223 Vilnius, Lithuania, Taraskevicius@geo.lt, Zinkute@geo.lt \\ ${ }^{2}$ Laboratory of Mycology, Nature Research Centre Institute of Botany, Žaliụjų Ežerų 49, LT-08406 Vilnius, Lithuania, \\ Jurga.Motiejunaite@botanika.It
}

\begin{abstract}
The area where the colony of great cormorants in Curonian Spit (Lithuania) prospers from 1989 is the study object of "Koreko" project. Based on geochemical results of 90 samples of topsoil from 6 zones which differ according to the influence of the great cormorants the following main accumulating chemical elements were revealed: $\mathrm{S}, \mathrm{Cu}, \mathrm{P}, \mathrm{Cl}, \mathrm{Ti}$ and $\mathrm{Ca}$. The contents of some other harmful chemical elements $(\mathrm{Cr}, \mathrm{Zn}$, $\mathrm{Ni}, \mathrm{Pb}$ and $\mathrm{Sb}$ ) are also elevated in the influence zones of cormorants. Energy-dispersive analysis was used for determination of the contents of 33 chemical elements.
\end{abstract}

Keywords: great cormorant colony, topsoil, XRF analysis

\section{Introduction}

The number of cormorants increases in various European countries. In forests with their dense colonies not only tree branches fall down on the forest litter, but also huge amount of cormorant excrements which can exceed $1 \mathrm{t} / \mathrm{ha}$ per month. So there is drastic influence of cormorants on forest ecosystem. Though the colony of the great cormorants near Juodkrante town in the northern part of the Curonian Spit settled only in 1989 and despite that since 2004 different measures were taken to restrict its spreading and successful breeding, the area affected by cormorants exceeds 19 ha. Geochemical disbalance caused by them can be one of the possible reasons of natural ecosystem disturbance. The project "Koreko" is aimed at interdisciplinary investigation in order to reveal environmental changes caused by cormorants. Pedogeochemical investigations of topsoil comprised part of this study. The aim of this research is to reveal chemical elements with anomalous contents which are unusual for background (natural) soil of Curonian Spit.

\section{Materials and Methods}

Topsoil sampling was done in 6 zones which differ according to the influence of cormorants: $\mathrm{E}$ and $\mathrm{F}$ zones are relatively less influenced and were used as background, D zone (transitional) is characterized by their moderate activity, $\mathrm{C}$ zone is distinguished by their active breeding (many nests), meanwhile $\mathrm{B}$ and $\mathrm{A}$ are mostly devastated zones with dead forest. In each zone 3 sites were selected and 5 samples were taken from each site. All samples were analysed by energy-dispersive X-ray fluorescence equipment SPECTRO XEPOS with TurboQuant for pressed pellets calibration method for determination of total contents of $\mathrm{Al}, \mathrm{Ba}, \mathrm{Ca}, \mathrm{Ce}, \mathrm{Cl}, \mathrm{Cr}$, $\mathrm{Cu}, \mathrm{Fe}, \mathrm{Ga}, \mathrm{Hf}, \mathrm{I}, \mathrm{K}, \mathrm{Mg}, \mathrm{Mn}, \mathrm{Mo}, \mathrm{Na}, \mathrm{Nb}, \mathrm{Ni}, \mathrm{P}, \mathrm{Pb}, \mathrm{Rb}$, $\mathrm{S}, \mathrm{Sb}, \mathrm{Th}, \mathrm{Si}, \mathrm{Sn}, \mathrm{Sr}, \mathrm{Te}, \mathrm{Ti}, \mathrm{Y}, \mathrm{Zn}, \mathrm{V}, \mathrm{Zr}$. In search of possible anomalies of chemical elements their maximum contents in $\mathrm{A}$ and $\mathrm{B}$ zones were divided by respective minimum contents from $\mathrm{E}$ and $\mathrm{F}$ zones.

\section{Results and Discussion}

The following 6 chemical elements had the highest $(>3)$ enrichment factors: $\mathrm{S}$ (120), $\mathrm{Cu}$ (12.5), $\mathrm{P}(7.7), \mathrm{Cl}(5.8)$, $\mathrm{Ti}(4.1), \mathrm{Ca}(3.7)$. Lower than 3 but higher than 2 enrichment factors were characteristic of $\mathrm{Cr}, \mathrm{Zn}, \mathrm{Nb}, \mathrm{Ni}$, $\mathrm{I}, \mathrm{Hf}, \mathrm{Pb}, \mathrm{Zr}, \mathrm{Fe}$ and $\mathrm{Mn}$, meanwhile lower than 2 but higher than 1.3 - of Th, Y, Mg, Ga, Si, Te, Sb. So the set of anomalous chemical elements includes not only usual harmful elements $\mathrm{Cr}, \mathrm{Zn}, \mathrm{Ni}, \mathrm{Pb}$ and $\mathrm{Sb}$, but also important elements of parent rocks $\mathrm{Ti}, \mathrm{Fe}, \mathrm{Mg}, \mathrm{Si}, \mathrm{Zr}$. Presumably anomalous contents of some chemical elements were caused by natural geochemical properties of parent rocks. Normalisation by conservative chemical 
element as well as chemical analysis of excrements of cormorants could help to distinguish the elements with anomalies caused by cormorants.

\section{Conclusion}

Pedogeochemical anomalies caused by excrements of great cormorants are characterised by the prevalence of $\mathrm{S}, \mathrm{Cu}, \mathrm{P}, \mathrm{Cl}, \mathrm{Ti}$ and $\mathrm{Ca}$. The contents of other harmful chemical elements $(\mathrm{Cr}, \mathrm{Zn}, \mathrm{Ni}, \mathrm{Pb}$ ir $\mathrm{Sb})$ are also elevated in their influence zones. The final decision about accumulating chemical elements can be done after normalisation by conservative chemical element and analysis of excrements of cormorants.

\section{Acknowledgements}

The authors are grateful to Research Council of Lithuania for financial support of project "Koreko", registration No LEK-12001). 